Beyond Philology No. 15/4, 2018

ISSN 1732-1220, eISSN 2451-1498

\title{
The demotic tongue of mateship in Australian Great War literature: The vernacular humourist
}

\author{
DOMINIC P. G. SHERIDAN
}

Received 31.01.2018, received in revised form 15.07.2018, accepted 30.11.2018.

\begin{abstract}
This paper looks at the demotic tongue of mateship in Australian Great War Literature as a theme of cognition and understanding in the literary texts and texts of culture. The language, like the Australian, was filled with character and a sense of the larrikin. It seemed irreverent at times, even rude in some circles, but it was much more than its immediate sound or inference; it was the natural verbal essence of the Australian mind - honest, loyal, dutiful and humorous. These characteristics are cornerstones of Australian mateship, a type of friendship that would be there beyond the bitter end, rival the love of a woman and even the protection of one's own life. For some Australians, poetry was merely an extension of this language, as language was merely an extension of friendship.

The aim of this paper is to demonstrate the Australian use of humour and language in the setting of Great War poetry. It looks at the demotic tongue of mateship, specifically what is known as the Great Australian Adjective (bloody), along with several other examples of vernacular language, in Australian Great War Literature, and considers this by referring to the common language of the Australian poet from the time. It will consider the notion that Australian writers of the Great War era may have been misunderstood as a result of their language, leading to critical mistakes about a poem's literary worth, a poet's seriousness as a poet and a nation's literary value.
\end{abstract}




\title{
Keywords
}

demotic, vernacular, bloody, mateship, tmesis

\section{Język potoczny w australijskiej literaturze I wojny światowej: humor i przyjaźń}

\begin{abstract}
Abstrakt
W niniejszym artykule poruszany jest aspekt języka potocznego australijskiej literatury I wojny światowej. W niektórych kręgach język potoczny w tym okresie sprawiał wrażenie braku taktu i uprzejmości, a jednak był przy tym naturalna ekspresja istoty australijskiego umysłu - była to mowa szczera i pełna humoru. Te szlachetne cechy, do których dołożyć należy jeszcze lojalność, sa najważniejszymi elementami australijskiego „mateship”, tego rodzaju przyjaźni, która istnieje ponad wszystko, rywalizuje $z$ miłościa kobiety, a nawet żąda poświęcenia własnego życia. Dla Australijczyków poezja była emanacją tego języka, i co się z tym wiąże, tak rozumianej przyjaźni.

Celem tego artykułu jest ukazanie kolorytu mowy potocznej australijskiej poezji I Wojny Światowej. Jednym z przykładów jest tutaj użycie „wielkiego australijskiego przymiotnika „bloody”, który do czasów obecnych jest powszechnie nadużywanym przymiotnikiem w Australii. Brak zrozumienia dla sensu użycia języka potocznego w poezji tamtego okresu, prowadziło nierzadko do krytycznych błędów dotyczących oceny wartości literackiej wiersza, powagi twórcy jako poety i wartości społecznej utworu.
\end{abstract}

\section{Słowa kluczowe}

język potoczny, wernakularny, bloody, mateship, tmesis

\section{Introduction}

The aim of this paper is to demonstrate the Australian use of humour and language in the setting of Great War poetry, and in so doing, identify how misunderstandings about a culture 
can arise. For this reason it will be important to look briefly at such notions as intended meaning and biographical criticism. The paper looks at the demotic tongue of mateship, specifically what is known as the Great Australian Adjective (bloody), along with several other examples of vernacular language, in Australian Great War Literature, and considers this by referring to the common language of the Australian poet from the time. Importantly, mateship may be defined as a type of friendship that would be there beyond the bitter end, rival the love of a woman and even override the protection of one's own life. While the so called Great Australian Adjective, bloody, is a word known in other countries, it was only known under the aforementioned title by Australians. This paper will consider the notion that Australian writers of the Great War era may have been misunderstood as a result of their language, leading to critical mistakes by the average reader about a poem's literary worth, a poet's seriousness as a poet and a nation's literary value. By including the poetry which appears here, it should become easier for the reader to recognise the poet's intended meaning as opposed to the average reader's assumed meaning. The close reading of these poems will provide the reader with a sense of the poet's cultural background and thus, in the context of the war and Australia at the time, it will become easier to recognise the poem's literary worth and the poet's seriousness as a poet. To this end, it will become easier to recognise the literary value of Australian Great War poetry.

This paper will track the following line of reasoning which demonstrates how an understanding of Australian Great War poetry brings the reader to recognise how Australian poets equated personal identity through the language they used. Language and humour are prone to misunderstandings when there is no access to the writer's cultural background. Further, humour has a place in serious literature, and for the Australian, it characterised him as the "subject" being spoken about. This subject, while humorous and irreverent, transcended the vulgar. But it requires broader understanding. The use of what 
appears as non-sophisticated language was not specifically Australian, but it was how the Australian found personal identification. And finally, as is seen in much of the Australian Great War poetry canon, the demotic tongue is indicative of the Australian mateship of the time.

\section{The misunderstanding: Language and humour}

It may be an obvious statement to make that the words we use do not fully capture the meaning we wish to convey, and that the average reader should consider more than the word itself in order to understand the intended meaning of the text, and it is the intended meaning here which is important. If this knowledge is of no account, then once the poet has finished the writing process, the reader will have all they need to know, thus obtaining an assumed meaning. However, this gives rise to a grave misunderstanding for the readers of many Australian Great War poems. Without some knowledge of the poet's cultural baggage, the average reader will not understand the intended meaning, but rather obtain an assumed meaning. The assumed meaning, as opposed to the intended, may thus generate critical mistakes about a poem's literary worth, a poet's seriousness as a poet and a nation's literary value.

The problem may be similar to the juxtaposition between historical experience and historical intuition, where the past informs the historian as opposed to the historian shaping the past respectively. On one hand we have literary experience, where the poem is understood in its context (both historically and biographically), and on the other hand we have literary intuition, where the average reader imposes their own abstractions onto the text. But this intuition is unreliable at best and damaging at worst. It is unreliable in as much as it fails to convey the intended meaning, and damaging in as much as it helps form misconceptions about national identity.

What is needed is not an approach to this poetry which negates the relevance of the writer, but rather a biographical crit- 
icism approach. The average reader will have a better appreciation of such poets as the Australian Oliver Hogue's or the Englishman Wilfred Owen's war poetry, for example, through biographical criticism as opposed to any form of criticism which lacks at least some knowledge of the poet's background. ${ }^{1}$ However, the damage to national literary value may be somewhat more endemic to a misunderstanding of Australian vernacular wartime poetry than it is with the poetry of the Englishman, Wilfred Owen. Australian Great War poetry requires more than a mere understanding of words; it requires, at the very least, a cultural understanding which is sympathetic and an openness to look beyond the mere word.

The language, like the Australian, is filled with character and a sense of the larrikin. ${ }^{2}$ It seems irreverent at times, even rude in some circles, but it is much more than its immediate sound or inference; it is the natural verbal essence of the Australian mind - honest, loyal, dutiful and humorous. These characteristics are cornerstones of Australian mateship as defined earlier. The egalitarianism of the Australian notion of calling a spade a spade was instinctively blind to the frail social conventions of "polite society". The larrikin poet, who sailed from Australia to Egypt and then marched to Gallipoli, through the Sinai Desert and the Western Front, saw nothing wrong in using his native vernacular language to convey his poetic thoughts about the war.

For some Australians, poetry is merely an extension of this language, as language is itself an extension of friendship, because we all recognise that actions speak louder than words. Actions, we might say, are in essence the true and universally readable literature of friendship - discernible by any nationali-

1 Wilfred Owen is included here because, while he is English, he will be more readily recognisable to non-Australian readers than the Australian, Oliver Hogue.

2 A larrikin may be commonly understood as a mischievous, uncultivated, rowdy but good hearted person, who acts with an apparent disregard for social or political conventions. However, the Australian larrikin is most essentially a good natured egalitarian who possesses a desire for a fair go and a laugh. 
ty or language group. It was this action which cemented the bonds of mateship throughout the war for soldiers of all nationalities. Yet, even actions may be interpreted without proper access to context. Actions, like war poetry, are bound in the context of the intended meaning and historical experience, not assumed meaning and historical intuition. By recognising this distinction, the average reader will make more accurate assessments of the literature and reduce any misunderstandings of its language and humour.

\section{Humour}

Australian Great War poetry has many faces - faces not unlike those found in British or American war poetry, such as patriotism, sarcasm, anger, sorrow, regret, humour and so on. However, Australian Great War poetry is also filled with the demotic tongue. It often times speaks in a way that can only be described as the earthy language of the everyday bloke on the street; the egalitarian who knows that his freedom of mind is not limited by his freedom of speech. That is to say, that his words are not the whole part of him. Words paint only a small picture when removed from context. This language is in many ways an enigma, because it is in one sense basic and coarse, while in another sense it is highly refined and elevated. This, of course, is the crux of the problem, for the Australian demotic poet may be considered as basic and coarse because of his word choice, but his intended meaning gives the average reader of discernment a glance into the highly refined and elevated nature of his human character. While this may also apply to other nationalities, it is only the Australian experience we are concerned with here, especially when we consider the relatively short literary history of Australia as opposed to England.

The Australian poet and scholar, Christopher Brennan (1870-1932), writing during the Great War, claimed that a poem is not a way of saying something, but a mode of that something's being (Gray and Lehmann 1991: 3). For many Australi- 
an poets, the "thing" here is mateship, and for the Australian, this is often presented in a way natural to the way average Australians speak to each other. The most prominent way is through humour. Mateship is a common theme in Australian demotic poetry, whether that theme is overt or underlying. Yet, Brennan's observation seems to identify that the intended meaning (the something's being) and not the assumed meaning (the way of saying something), is the important component to any poem and thus gives the poem its value and literary worth.

Professor David Daiches (1912-2005) states in his critical history of English literature: "The reintroduction of wit into serious poetry not only meant the revival of the pun as a serious poetic device, after its banishment from all but comic poetry for over two centuries, but also the realization that truly serious art transcends the vulgar and the everyday by including it, not by rejecting it" (Daiches 1994: 1126). The acknowledgement and use of vocabulary which was not considered intellectual, was part of the Australian approach to humour. Daiches held that this demotic language had re-emerged in literature at the beginning of the $20^{\text {th }}$ century and that the true value of the poem transcended the base nature of the language the poet might use. To this end, Australian war-time poetry was to give the Australian a coping mechanism which was al-

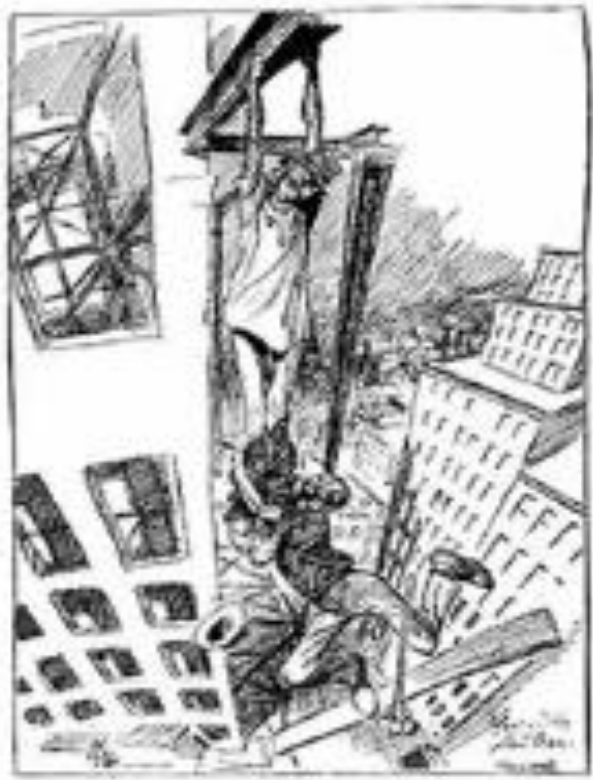

"For gronote, sup funghing : Ihis it seribus?"

Figure 1

For Gor'sake, stop laughing - this is serious ready bound up with his 
sense of self. We might call this the vernacular-humourist. The humour, which was bound in the language, vulgar and unintellectual as it may seem, gave the Australian a sense of home, safety and freedom from life's worries.

The cartoonist, Stan Cross (1888-1977), captured the Australian sense of laughing in the face of danger in his 1933 cartoon, "For gorsake! Stop laughing - this is serious." We see two Australian workmen hanging from the framework of a skyscraper, about to fall to their deaths. One is holding the steel beam and the other is holding onto his co-worker's pants, which have slid down his legs prompting them both to laugh at the stupidity of the situation. The one holding the beam says the famous line: "For gorsake! Stop laughing - this is serious." The irreverent usage of "gorsake", being indicative of the natural way of speaking in Australia, just as the way Australians would refer to the national anthem of England as the "gorsave", was all too common. While inherited from working class England, it was the way Australians spoke. However, the vernacular-humour was for the most part the driving force of the Australian's words.

The much loved Australian comic poet, C. J. Dennis (18761938), once said of his own verse that "slang is the illegitimate sister of poetry, and if an illegitimate relationship is the nearest I can get I am content". (McLaren 1981) Average Australians felt comfortable speaking in slang and abbreviation, for this was the common language of the street. As the term "demotic" implies, the common language is the language of the common people, and nothing more. For Dennis, language was everything. His use of the demotic tongue, with his particular Australian flavour, was so popular in Australia, that it was immortalised in the numerous comical books and poems he wrote. Such books as The Sentimental Bloke and its sequel The

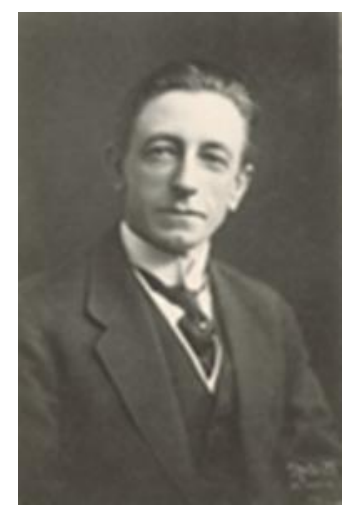

Figure 2 C. J. Dennis 
Moods of Ginger Mick, Doreen, Digger Smith and others, and the most wonderful and descriptive poem The battle of the Wazzir, were all overflowing with Dennis' prolific demotic tongue. One might call Dennis a genius of the Australian character. He was most certainly an Australian vernacular wordsmith of far-reaching humoristic virtuosity.

\section{The great Australian adjective}

In 1908, a national song competition was held to write the words for a new national anthem, and when C. J. Dennis submitted his text, the organisers thought they were getting something like the Marseillaise with its tremendous sense of patriotic fervour and zeal, but what they got instead was something called the Austral-aise. At first glance it may not seem so patriotic, at least, not in the same ways as the Marseillaise, but looking deeper into the context and the intended meaning, it is every bit as patriotic as the Marseillaise. The average reader, who may obtain an assumed meaning rather than understand the intended meaning, may consider Dennis' poem as nothing more than a joke; not to be taken as serious poetry because of the fact that in almost every line there appears the word bloody. Daiches would consider this word as nothing more than a literary device used by Dennis to arouse the natural humour of the average Australian; a linking device between the poet and the poet's cultural background which made the intended meaning more accessible to the Australian on the street. The only requirement here was that the reader understand that the use of the word bloody was not intended as a vulgarity, like some schoolchild who writes such words on the lavatory wall, but was intended rather to evoke the common man's intellect by use of the demotic tongue. To this end, Dennis merely made the high culture of poetry more accessible to the average man who would not usually have access to, or inclination to read the musings of the sometimes esoteric concerns of fine literature. Dennis' The Austral-aise must stand as 
the quintessential example of this demotic tongue and its usage. The following is the first stanza and verse of the seven stanza poem (Dennis 1918: 84-86).

Fellers of Australier,

Blokes an' coves an' coots,

Shift yer ---- carcases,

Move yer ---- boots.

Gird yer ---- loins up,

Get yer ---- gun,

Set the ---- enermy

An' watch the ----3 run.

Chorus:

Get a ---- move on,

Have some ---- sense.

Learn the ---- art of

Self de- ---- -fence.

Though Dennis wrote it as a joke, it became incredibly popular and was used as a recruitment song for the 1914-1918 war. It is filled with dutiful humour. Dennis' use in almost every line of the Great Australian Adjective, that is to say bloody, was to strike a common chord with Australians. It was the most common of words in Australia, and could be used for almost anything adjectival - even adverbial at times. It had both positive and negative uses; something could be bloody bonza or bloody bleak. Australians then and now would say of any inclement weather - bloody weather. It was then and is now a case of bloody this and bloody that. Nothing was or is sacrosanct when it came to the use of the Great Australian Adjective, and Dennis was able to let it flow from his pen as though the word was somehow part of the ink itself. As noted earlier, the word bloody was used in other English-speaking countries, but it may benefit us here to realise that it was only in Australia that this word was given some form of grammatical, or terminological status.

3 buggers - the last gap here is the noun bugger, not the adjective bloody. 
We may also observe the use of tmesis in this poem. That is to say, the separating of a word with another word. Used only informally, it provides poetic colour and rhythm that could give the Australian poet a certain flavour unobtainable by the conventional poet. The Australian writer John O'Grady (19071981) provides some good examples of tmesis in his 1959 poem on the subject; The Integrated Adjective. We can see some examples from O'Grady's poem here: forty-bloody-seven, good e-bloody-nough, kanga-bloody-roos, Tumba-bloody-rumba 4 and me-bloody-self. In Dennis' poem earlier, we saw several examples: Australi-bloody-ar, Ad-bloody-vance, Spifler-bloody-cate, Enthusi-bloody-asm, kingdom-bloody-come, Pos-bloody-terity and Self de-bloody-fence.

The use of tmesis is a very common thing in the demotic tongue of the Australian vernacular-humourist. Most Australians have the natural tendency to call a spade a bloody shovel as it is simply the average Australian's way. However, it will invariably lead the listener to obtain an assumed meaning rather than understand the intended meaning. This, we might recognise as the cultural inflective which may not be translated without some understanding of the speaker's background. However, for the purposes of this paper, we might restrict our study to the poem in its written form.

Interestingly, $\mathrm{W}$. T. Goodge The Colonel (1862-1909) wrote a poem in 1898 called "__!" (The Great Australian Adjective!), and it shone the first literary light on the use of this word. Its printed use certainly indicates its common verbal use in the street by the average Australian, but it may be considered as the literary inspiration for C. J. Dennis' Australaise, even though Dennis would have heard it used regularly in the streets of Auburn (where

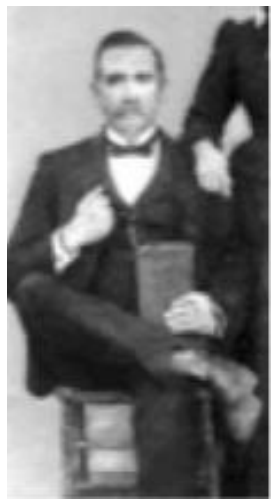

Figure 3 W. T. Goodge

4 Tumbarumba is a town in New South Wales, south-west of Sydney, Australia. 
he was born), Adelaide, Broken Hill, Melbourne and Sydney among others (where he worked). Yet Goodge's poem gave Australian literature one of its first glimpses of a growing national identity; an identity that could easily be misunderstood by those who assumed meaning rather than understood the intended meaning. The first stanza of four goes as follows (Goodge 1972: 115):

The sunburnt - stockman stood

And, in a dismal - mood,

Apostrophised his — cuddy;

The — nag's no — good,

He couldn't earn his _ food-

A regular — brumby,

- !"

We might also recognise the use of this Great Australian Adjective in another very popular song from the time: The Ragtime Army. There are several versions of this song. It was originally an English song and the Australians decided to make their own version. The first stanza is the most famous. While it has an element of patriotism about it, the song also has a strong element of boredom, which was often the daily fare of the soldier in the trench. This boredom led to an Australian trench-song which goes as follows: "We're here because we're here, because we're here because we're here". ${ }^{5}$ (Nicholas 47) However, The Ragtime Army also demonstrated the humorous mateship of the Australians in both life and respectful remembrance after death. What follows is this anonymous song, sung by most Australians at one time or another during the war (Graham 2004: 52-53).

We are the Ragtime Army

The A-N-Z-A-C,

We cannot shoot, we won't salute,

${ }^{5}$ A marching song to the tune of Auld Lang Syne. This monotonous ditty aptly expressed the frustration and frequent futility of the war. 
What bloody good are we?

And when we get to Berlin,

The Kaiser he will say,

'Hoch! Hoch! Mein Gott!'

What a bloody rotten lot

To get six bob a day. ${ }^{6}$

We are the only heroes

Who stormed the Dardanelles,

And when we get to Berlin

They'll say, 'What bloody sells'.

You boast and skite from morn to night

And think you're very brave,

But the men who really did the job

Are dead and in their graves.

Another word often used in place of bloody was blooming. In a poem by Tom Skeyhill (1895-1932), the blind Australian soldier poet who briefly lost his sight while serving at Gallipoli and went on to write a famous book called Sergeant York and The Great War (later made into a 1941 film starring Gary Cooper), we see this word used in place of bloody. Skeyhill's poetry is filled with the demotic tongue, as he wanted to capture the mood of the average Australian in the trench.

The poem is called "Me Brother what Stayed at 'ome", and it is written in the way many Australians spoke at the time. Dropping the "g" was only one of the common spoken forms, while dropping the first letter was indicative of the Australian's natural fondness of the Cockney way of speaking which Austral-

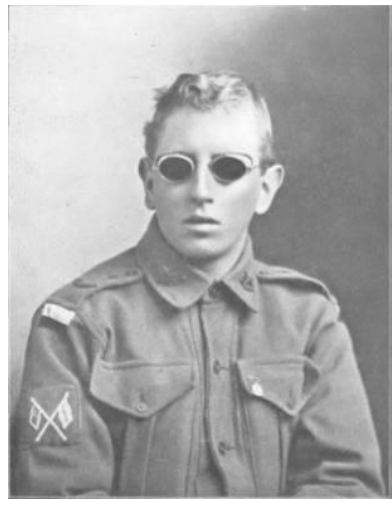

Figure 4 Tom Skeyhill

6 Of note, the term ANZAC was the designated acronym for Australian New Zealand Army Corps, and six bob was about 60 cents, which was good money during the war. 
ians inherited in some ways - even developing an Australian form of Cockney slang.

Most commonly, Australians used the pronoun me in place of $m y$, as is seen in the title, as well as what in place of that or who. Off became orf and Australia became Stralia. Skeyhill's use of these forms identify his written attachment to the spoken word. He wrote as the average Australian spoke, and in so doing, he demonstrated the musicality of the Australian phrase as it was spoken, albeit inherited from the English working-class. The language then lent itself to the lyricism of the Australian way of speaking. The first stanza of Skeyhill's poem, written in May of 1915 at Cape Helles, Gallipoli, shows that Australians considered their fellow countrymen as brothers, and the fact that some had not come to fight alongside their brothers at war was unnatural and frustrating (Skeyhill 1915: 20-24).

I'm pullin' orf me colours

And slingin' me Webb away.

I'm goin' back to Cairo,

To draw me bloomin' pay.

I'm fed up with bein' a soldier,

So 'elp me bob, I am-

Of chewin' mouldy biscuits

And eatin' bread an' jam.

I'm sick of fightin' Turkeys

Out on me bloomin' own,

When I thinks of 'im in 'Stralia-

Me Brother Wot Stayed at 'Ome.

To see this style of writing at its best, I highly recommend reading C.J. Dennis' The Songs of the Sentimental Bloke and The Moods of Ginger Mick, however, this comes with a warning, because it is quite a difficult read and no dictionary will help, even though Dennis included a valuable glossary at the end of the Sentimental Bloke. It is pure slanguage from arguably Australia's greatest vernacular-humourist. 


\section{A general use of the demotic - mateship}

However, Skeyhill's Brother what stayed at 'ome was outweighed by the value of mateship. The much loved Australian poet, Henry Lawson (1867-1922), said in a poem he wrote in 1914 that "No matter what a mate may do, / A mate can do no wrong!" (Lawson 1916: 111-112) which was the prevailing attitude in Australia. Mateship was the consensual locus of the interlocutor exchange. It was the place where anything was acceptable and everything was safe. As Lawson had said, "A mate can do no wrong". The demotic tongue was naturally understood by the mate, who understood the intended meaning, looking past the mere words being used. For the stranger, that is to say, someone who did not know the speaking mates, or did not know something about their vernacular background, the best they could hope for was to obtain an assumed meaning. Without some knowledge of the interlocutory mates, the stranger will struggle with intended meaning.

In a poem by Australian-born Edward Dyson (1865-1931), called "Billjim", we observe that Lawson's "mateship" was the driving force behind all Australians at war. But we also see the use of the demotic tongue in Dyson's poem. Certain grammatical anomalies, which we may ascribe to the wonderful poetic tool, poet's privilege, may be observed throughout. The poem's title was the name given to all Australians during the Great War. It was the most normal thing in the world; where there was one Australian, there was his mate beside him, so, where there was Bill, there was Jim, hence Billjim. All Australian soldiers during the Great War were referred to as Billjim, and where there were two or more together, they were Billjims. The following is the first and last stanzas of the eight stanza poem: (Dyson 1919: 21-22).

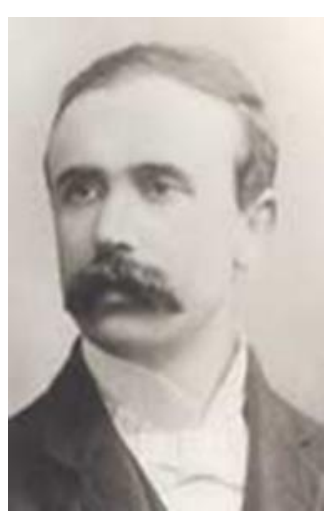

Figure 5

Edward Dyson 
Down to it is Plugger Bill,

Lyin' crumpled, white 'n' still.

Me 'n' him

Chips in when the scrap begins,

Carin' nothin' for our skins,

Chi-iked as the 'Eavenly Twins-

Bill 'n' Jim.

Mate o' mine, yiv stayed it through.

Hard luck, Bill-for me 'n' you

Hard 'n' grim.

They have got me Cobber true,

But I'm stickin' tight ez glue. . . .

Bill, there's one who'll plug for two-

It is Jim!

Dyson's "Billjim" serves as a classic example of the demotic tongue of mateship. The two soldiers Bill and Jim were forever by each other's side, and this was the most natural of things. Dyson's Billjim stands in stark contrast to Skeyhill's "Me Brother What Stayed at 'ome". While Skeyhill's brother was a shirker, Skeyhill demonstrated the unnaturalness by becoming fed up with the war. Because his brother was not there with him, the war was intolerable and unacceptable. The true loss was the loss of his brother; an end of mateship. But Dyson's Billjim identifies a rather different loss. Dyson recognises that loss of life is not loss of mateship, as he ends his poem with "there's one who'll plug for two", ensuring that Jim will go on living and striving for the both of them. Again, we may see that Jim's actions speak louder than his mere words. Dyson's intended meaning shows the true essence of mateship here. The mateship never dies, even though the interlocutory mateship, in a purely physical way, does. Dyson's Billjim and Skeyhill's Brother, through the demotic tongue, demonstrate the characteristics of mateship in their individual types of loss. 


\section{Conclusion}

We may note then, that many Australian poets of the Great War wrote in a language style which was commonly heard on the lips of their fellow countrymen. They wrote as they spoke. It was as natural as breathing. In many cases, this demotic language gave the impression of an illiterate caveman, yet, when we look deeper at the poetry of these men, we see that the poetry captures perfectly the essence of the average man in the street, who had thoughts and dreams, valued mateship above all and spoke in a vernacular-humour.

The poet's intended meaning is sometimes misunderstood by the average reader's assumed meaning, and because of this, the reader may generate critical mistakes about the poem's literary worth and the poet's seriousness as a poet. Of course, this will not necessarily apply to formal and rigorous analysis, but rather to the average reader. However, the main danger is that the average reader may make incorrect assumptions about a nation's literary value. As Daiches asserted, serious poetry transcends the vulgar by including it, not by rejecting it, and to this end, the demotic tongue of Australian mateship must be understood through a biographical criticism approach as opposed to any approach which does not take into account the author's background.

So it may seem that the understanding of the deeper poem may be hidden to some extent by the misunderstanding of the cultural language. In many ways, we might see this way of speech as a language in itself; a language, like the people, which is inspired by good humour and mateship, and a people who may sometimes be misunderstood as less serious than others.

It does not matter so much that the Australian vernacular had its origins from working-class England to a large degree, but it does matter that Australians found self-identification in their use of it, and that through this usage, Australian vernacular poets may seem less serious than their English coun- 
terparts. This, as is demonstrated by the poetry included in this paper, gives good reason to recognise the importance of intended meaning and biographical criticism.

\section{References}

Daiches, D. (1994). A Critical History of English Literature. Volume II. The Restoration to the Present Day. London: Mandarin.

Dennis, C. J. (1918). Backblock Ballads and Later Verses. Sydney: Angus \& Robertson.

Dennis, C. J. (1915). The Songs of a Sentimental Bloke. Sydney: Angus \& Robertson.

Dyson, E. (1919). "Hello, Soldier": Khaki Verse. Melbourne: McKinley and Co., Cole's Book Arcade.

Gray, R., G. Lehmann (eds.) (1991). Australian Poetry in the Twentieth Century. Port Melbourne: Minerva.

Goodge, W. T. (1972). Hits! Skits! And Jingles! Wollstonecraft: Pollard Publishing.

Lawson, H. (1916). Song of the Dardanelles and Other Verses. London: George G. Harrap.

McLaren, Ian F. (1981). Australian Dictionary of Biography: Dennis, Clarence Michael James (1876-1938). Available at <http://adb.an u.edu.au/biography/dennis-clarence-michael-james-5957>. Accessed 10.07.2017.

Nicholas, A. S. (ed.) (1938). Patches. Adelaide: Australian Army Medical Corps.

Seal, G. (2004). Inventing Anzac: The Digger and National Mythology. St Lucia: University of Queensland Press.

Skeyhill, T. (1915). Soldier Songs from Anzac. Melbourne: George Robertson \& Company.

\section{Pictures}

Figure 1: Gamble, Brett (2006, December 31). For Gor'sake, stop laughing - this is serious: A look into Australian comic art. Available at <http://forgorsake.blogspot.com/>. Accessed 10.07.2017. 
Figure 2: Middlemiss, Perry (2011, December 24). Great Australian Author \#57 - C. J. Dennis. Available at <http://www.middlemiss. org/matilda/2011/12/>. Accessed 10.07.2017.

Figure 3: Joanne (NA). William Thomas Goodge Bio. Available at <https://mypoeticside.com/poets/william-thomas-goodge-poems \#block-bio>. Accessed 10.07.2017.

Figure 4: National Archives of Australia - Discovering Anzacs (2014). Tom Skeyhill. Available at <https://discoveringanzacs.naa.gov.au /browse/gallery/23180>. Accessed 10.07.2017.

Figure 5: High Beach (2017). A Dyson Bibliography. Available at <http://www.hibeach.net/dysonbks.html>. Accessed 10.07.2017.

Dominic P. G. Sheridan

ORCID iD: 0000-0001-7142-8037

University of Gdańsk

Institute of English and American Studies

Wita Stwosza 51

80-308 Gdańsk

Poland

dpg.sheridan@gmail.com 